\title{
Studi Numerik Pengaruh Radius Fillet dan Ketebalan Cap terhadap Tegangan Von Mises dan Faktor Keamanan Silinder Berdinding Tipis untuk Tabung Motor Roket
}

\author{
Lasinta Ari Nendra Wibawa, ${ }^{1, *}$ \\ ${ }^{1}$ Mahasiswa Pascasarjana Teknik Mesin, Universitas Sebelas Maret,Surakarta \\ ${ }^{2}$ Lembaga Penerbangan dan Antariksa Nasional (LAPAN) \\ *E-mail: lasinta.ari@lapan.go.id
}

\begin{abstract}
Abstrak
Motor roket adalah bagian penting dari roket. Motor roket bekerja menggunakan prinsip bejana tekan karena bekerja di lingkungan dengan tekanan dan suhu tinggi. Makalah ini menyelidiki tegangan von Mises yang terjadi dalam silinder berdinding tipis untuk tabung motor roket dan faktor keamanan karena pengaruh radius fillet dan ketebalan cap. Dimensi panjang silinder adalah $400 \mathrm{~mm}$, diameter luar $122 \mathrm{~mm}$, dan ketebalan dinding $5 \mathrm{~mm}$. Radius fillet divariasikan 2, 4, 6, dan $8 \mathrm{~mm}$, sedangkan ketebalan cap divariasikan 5 dan $10 \mathrm{~mm}$. Silinder berdinding tipis dikenai tekanan internal konstan yaitu $6 \mathrm{MPa}$. Analisis tegangan dilakukan menggunakan metode elemen hingga dengan perangkat lunak Ansys Workbench 2019 R3. Perbandingan nilai tegangan hoop dan longitudinal antara perhitungan analitik dan simulasi digunakan untuk proses verifikasi. Hasil simulasi menunjukkan bahwa ketika radius fillet dan ketebalan cap meningkat, tegangan Von Mises menurun. Material memiliki faktor keamanan lebih tinggi dari 1,25 ketika ketebalan cap $10 \mathrm{~mm}$ dengan radius fillet 4,6 , dan $8 \mathrm{~mm}$.
\end{abstract}

Received: 12 -02-2020; Accepted: 16-04-2020; Published online: 23-04-2020

Kata kunci: ansys; bejana tekan; metode elemen hingga; silinder berdinding tipis; tabung motor roket.

\begin{abstract}
The rocket motor is an important part of rockets. The rocket motor works using the pressure vessel principle because it works in an environment with high pressure and temperature. This paper investigates the von Mises stress that occurs in thin-walled cylinders and safety factors for rocket motor cases due to the influence of the fillet radius and cap thickness. Dimensions of the cylinder length are $400 \mathrm{~mm}$, outer diameter is $122 \mathrm{~mm}$, and wall thickness is $5 \mathrm{~mm}$. The fillet radius is varied 2, 4, 6, and $8 \mathrm{~mm}$, while the cap thickness is varied 5 and $10 \mathrm{~mm}$. Thin-walled cylinders are subjected to the constant internal pressure of $6 \mathrm{MPa}$. Stress analysis is performed using the finite element method with Ansys Workbench 2019 R3 software. A comparison of hoop and longitudinal stress values between analytical calculation and simulation are used for the verification process. The simulation results show that when the fillet radius and cap thickness increase, the Von Mises stress decreases. The materials have a safety factor higher than 1.25 when the thickness of the cap $10 \mathrm{~mm}$ with a fillet radius of 4, 6, and $8 \mathrm{~mm}$.
\end{abstract}

Keywords: ansys; pressure vessel; finite element method; thin-walled cylinder; rocket motor case.

\section{Pendahuluan}

Motor roket adalah bagian penting dari roket yang berisi bahan bakar untuk mendorong roket [1]. Motor roket terdiri dari tabung, nosel, cap, isolator, dan pemantik (igniter). Motor roket beroperasi dengan mengeluarkan gas suhu tinggi melalui nosel untuk menghasilkan daya dorong. Motor roket bekerja menggunakan prinsip seperti bejana tekan karena menyimpan bahan bakar propelan. Pada umumnya, motor roket bekerja di lingkungan dengan tekanan dan suhu tinggi [2].

Desain tabung motor roket tergantung pada tekanan internal dan bahan yang digunakan [3]. Tabung motor roket yang bekerja pada tekanan internal tinggi umumnya menggunakan silinder berdinding tebal (thick-walled cylinder), sedangkan pada tekanan internal rendah menggunakan silinder berdinding tipis (thin-walled cylinder). Material yang memiliki kekuatan tinggi biasanya menggunakan silinder berdinding tipis, sedangkan material yang memiliki kekuatan rendah menggunakan silinder berdinding tebal.

Tekanan internal, ketebalan dinding, dan panjang silinder adalah beberapa faktor yang mempengaruhi tegangan von Mises maksimum pada silinder berdinding tipis [4]. Faktor-faktor lain seperti radius fillet dan ketebalan cap juga turut 
berpengaruh pada silinder berdinding tipis. Tujuan dari penelitian ini adalah memprediksi tegangan von Mises dan faktor keamanan pada silinder berdinding tipis dengan variasi radius fillet dan ketebalan cap.

Pada penelitian ini, desain tabung motor roket menggunakan silinder berdinding tipis dengan panjang $400 \mathrm{~mm}$, diameter luar $122 \mathrm{~mm}$, dan ketebalan dinding $5 \mathrm{~mm}$. Radius fillet divariasikan 2, 4, 6, dan 8 mm, sedangkan ketebalan cap divariasikan 5 dan $10 \mathrm{~mm}$. Silinder berdinding tipis dikenai tekanan internal konstan yaitu $6 \mathrm{MPa}$.

Analisis tegangan menggunakan metode elemen hingga dengan perangkat lunak Ansys Workbench 2019 R3. Metode elemen hingga adalah teknik matematika numerik untuk menghitung kekuatan struktur komponen teknik dengan membagi obyek menjadi bentuk jala (mesh) [5][6], suatu elemen yang lebih kecil sehingga kalkulasi dapat diatur dan dijalankan. Metode elemen hingga bertujuan untuk menentukan struktur atau komponen dapat dengan aman menahan beban yang telah ditentukan [7]. Metode elemen hingga banyak digunakan untuk memprediksi tegangan pada silinder berdinding tipis dan berdinding tebal [8].

\section{Material dan metodologi}

Berdinding tipis dan berdinding tebal adalah klasifikasi bejana tekan berdasarkan dimensinya. Bejana tekan berdinding tipis adalah bejana tekan dengan ketebalan dinding $\left(t_{w}\right)$ lebih kecil dari 1/20 diameter internal $\left(D_{i}\right)$. Bejana tekan berdinding tebal adalah bejana tekan dengan ketebalan dinding $\left(t_{w}\right)$ lebih besar dari 1/20 diameter internalnya $\left(D_{i}\right)$.

Tegangan silinder berdinding tipis akan terjadi dalam tiga arah, yaitu hoop (circumferential), longitudinal (axial), dan radial. Persamaan tegangan maksimum silinder berdinding tipis pada arah (1) hoop, (2) longitudinal, dan (3) radial adalah:

$$
\begin{aligned}
& \left(\sigma_{h}\right)_{\text {max }}=\left(\frac{P_{i} D_{i}}{2 t}\right) \\
& \left(\sigma_{l}\right)_{\text {max }}=\left(\frac{P_{i} D_{i}}{4 t}\right) \\
& \left(\sigma_{r}\right)_{\text {max }}=-p_{i}
\end{aligned}
$$

dimana $\mathrm{p}_{\mathrm{i}}$ adalah tekanan internal tabung silinder $(\mathrm{MPa}), \mathrm{D}_{\mathrm{i}}$ adalah diameter dalam silinder $(\mathrm{mm})$, dan $\mathrm{t}$ adalah tebal dinding silinder $(\mathrm{mm})$. Sedangkan $\left(\sigma_{h}\right)_{\max }$ adalah tegangan hoop maksimum, $\left(\sigma_{l}\right)_{\text {max }}$ adalah tegangan longitudinal maksimum, dan $\left(\sigma_{r}\right)_{\text {max }}$ adalah tegangan radial maksimum.

Analisis tegangan pada tabung motor roket menggunakan metode elemen hingga dengan perangkat lunak Ansys Workbench 2019 R3. Analisis elemen hingga merupakan salah satu metode numerik yang sangat familiar digunakan untuk menghitung setiap fenomena fisik seperti perilaku struktur atau fluida, perpindahan panas, dan elektromagnetik komponen teknik. Metode ini memungkinkan setiap desain produk dianalisis dengan rinci dan mengurangi jumlah prototipe fisik sehingga memudahkan dalam mengembangkan produk yang lebih baik dengan waktu yang lebih cepat. Salah satu perangkat lunak yang cukup populer digunakan dalam analisis elemen hingga adalah Ansys. Ansys banyak digunakan untuk mengukur konsentrasi tegangan dalam silinder berdinding tebal dan berdinding tipis [8].

Penyelesaian persoalan hukum fisika yang bergantung pada ruang dan waktu biasanya dinyatakan dalam persamaan diferensial parsial (Partial Differential Equations). Pada sebagian besar kasus dan geometri, persamaan diferensial parsial tidak dapat diselesaikan dengan metode analitis. Namun, pendekatan persamaan dapat dibangun, biasanya didasarkan 
pada berbagai jenis diskritisasi. Metode diskritisasi ini mendekati persamaan diferensial parsial dengan persamaan model numerik, yang dapat diselesaikan dengan menggunakan metode numerik. Dengan kata lain, solusi untuk persamaan model numerik merupakan pendekatan dari solusi nyata untuk persamaan diferensial parsial.

Prosedur metode elemen hingga memungkinkan kontinum didiskritisasi menjadi sejumlah bagian (elemen) yang terbatas dan menekankan bahwa karakteristik domain kontinu dapat diperkirakan dengan merakit sifat-sifat yang sama dari elemen-elemen diskrit per node. Proses ini dikenal sebagai diskritisasi. Nilai-nilai antara node ditentukan dari interpolasi polinomial menggunakan metode matriks komputasi dan akurasi hasil tergantung pada diskritisasi, akurasi bentuk interpolasi yang diasumsikan, dan akurasi metode solusi komputasi. Metode elemen hingga sangat popular karena kemampuannya untuk memodelkan banyak persoalan numerik terlepas dari geometri, kondisi batas, dan pembebanan.

Gambar 1 menunjukkan model geometri silinder. Karena silinder menunjukkan simetri pada arah longitudinal (axial), maka silinder dapat dimodelkan dengan setengah bagian atasnya [9]. Penelitian ini menggunakan segmen 90 derajat dari model silinder padat atau seperdelapan silinder (Gambar 2). Hal ini mewakili karena tekanan yang diberikan pada fluida dalam silinder tertutup maka tekanan tersebut akan diteruskan sama besar dan merata ke semua arah [10].

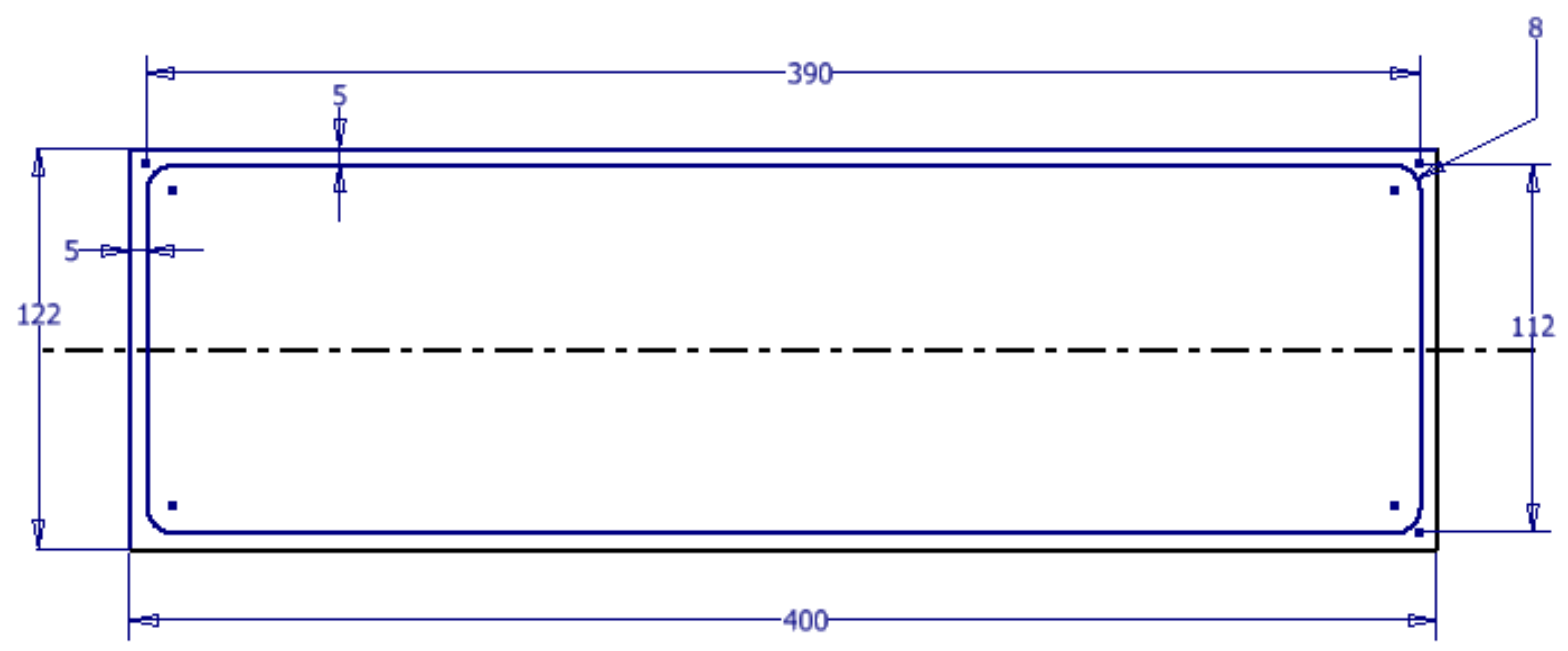

Gambar 1. Desain silinder berdinding tipis dengan ketebalan cap $5 \mathrm{~mm}$ dan radius fillet $8 \mathrm{~mm}$.

Asumsi berikut dibuat secara teoritis pada silinder berdinding tipis: (1) Material Aluminium 6061 homogen dan isotropik. (2) Bagian silinder tetap rata bahkan setelah diberi tekanan internal. (3) Semua permukaan silinder akan mengembang atau berkontraksi secara independen.

Kondisi batas menggunakan perangkat lunak Ansys Workbench 2019 R3 ditunjukkan pada Gambar 3 dan parameter analisis elemen hingga pada Tabel 1. Ukuran elemen yang digunakan diatur seragam, yaitu $3 \mathrm{~mm}$. Hal ini berakibat jumlah node dan elemen untuk masing-masing variabel ada sedikit perbedaan, tetapi tidak terlalu berbeda signifikan.

Kriteria untuk material tabung motor roket adalah ringan dan memiliki kekuatan tinggi. Aluminium 6061 dipilih untuk material tersebut [11]. Sifat mekanik Aluminium 6061 ditunjukkan pada Tabel 2. 


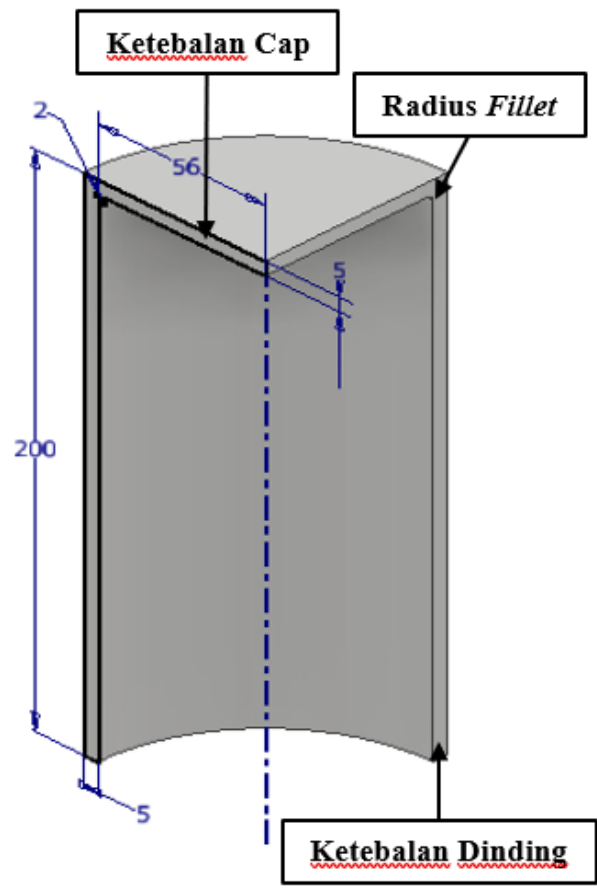

Gambar 2. Bagian satu per delapan dari silinder dengan radius fillet $2 \mathrm{~mm}$ dan ketebalan cap $5 \mathrm{~mm}$

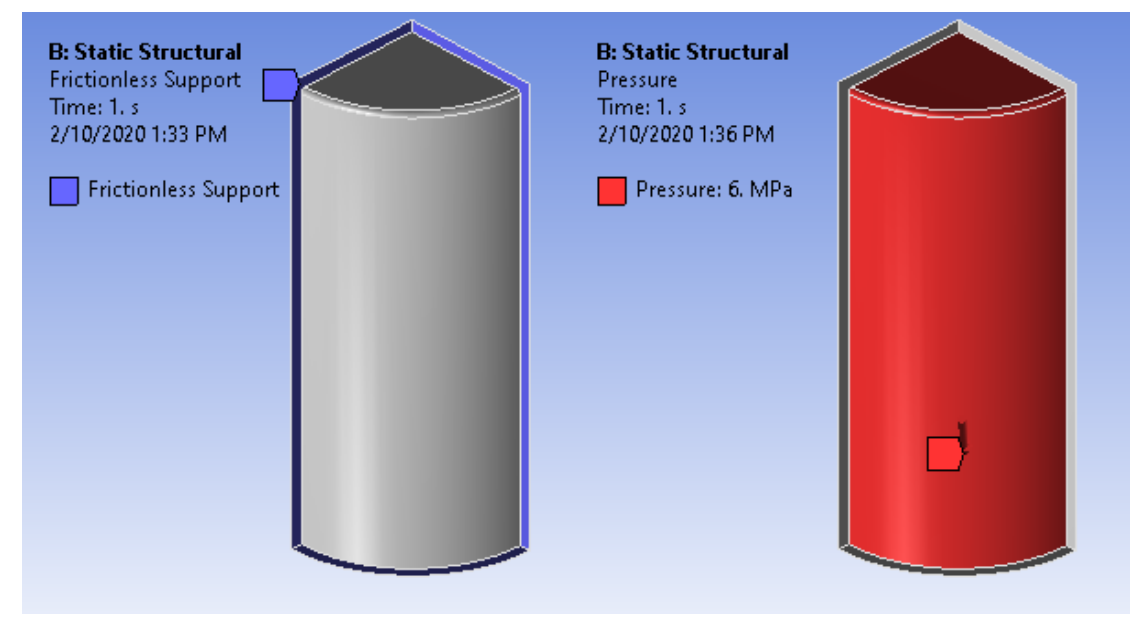

Gambar 3. Kondisi batas: jenis constraint (kiri) dan kondisi pembebanan (kanan)

Tabel 1. Parameter analisis elemen hingga

\begin{tabular}{lll}
\hline Parameter & Notasi & Nilai \\
\hline Panjang silinder & $\mathrm{L}$ & $300 \mathrm{~mm}$ \\
Diameter luar silinder & $\mathrm{D}_{\mathrm{o}}$ & $122 \mathrm{~mm}$ \\
Ketebalan dinding & $\mathrm{t}_{\mathrm{w}}$ & $5 \mathrm{~mm}$ \\
Radius fillet & - & $2,4,6$, dan $8 \mathrm{~mm}$ \\
Ketebalan cap & $\mathrm{t}_{\mathrm{c}}$ & $5 \mathrm{dan} 10 \mathrm{~mm}$ \\
Tekanan internal & $\mathrm{P}_{\mathrm{i}}$ & $6 \mathrm{MPa}$ \\
Ukuran elemen & - & $3 \mathrm{~mm}$ \\
\hline
\end{tabular}


Tabel 2. Sifat mekanik material Aluminium 6061 [12]

\begin{tabular}{llll}
\hline Material & Density $\left(\mathrm{gr} / \mathrm{cm}^{\mathbf{3}}\right)$ & Yield Strength $(\mathrm{MPa})$ & Tensile Strength $(\mathrm{MPa})$ \\
\hline Aluminium 6061 & 2,7 & 275 & 310 \\
\hline
\end{tabular}

\section{Hasil dan pembahasan}

Salah satu teori kegagalan didasarkan pada energi distorsi maksimum, yang dikenal sebagai kriteria von Mises. Tegangan von Mises menjadi faktor penentu apakah material akan mengalami kegagalan atau tidak [13]. Tegangan von Mises menghitung kombinasi tegangan pada titik tertentu yang akan menyebabkan kegagalan [14]. Material akan gagal ketika tegangan von Mises melebihi kekuatan material. Teori von Mises merupakan teori plastisitas yang berlaku paling baik untuk material ulet, terutama untuk material logam seperti Aluminium 6061 [15]. Tegangan von Mises juga dikenal sebagai tegangan ekuivalen [16].

Gambar 4 menunjukkan tegangan von Mises silinder dengan ketebalan cap $5 \mathrm{~mm}$ untuk radius fillet $2 \mathrm{~mm}$ (kiri) dan $4 \mathrm{~mm}$ (kanan). Hasil simulasi menunjukkan tegangan von Mises maksimum menurun seiring peningkatan radius fillet (Tabel 3). Hubungan antara radius fillet dan tegangan von Mises maksimum berbanding terbalik. Tegangan von Mises maksimum terjadi pada area cap. Area tersebut merupakan area kritis. Penelitian ini membuktikan tegangan von Mises maksimum dapat dikurangi dengan meningkatkan radius fillet, meskipun tanpa menambah ketebalan dinding silinder. Metode ini lebih efisien karena material akan lebih ringan dibanding dengan meningkatkan ketebalan silinder secara keseluruhan.

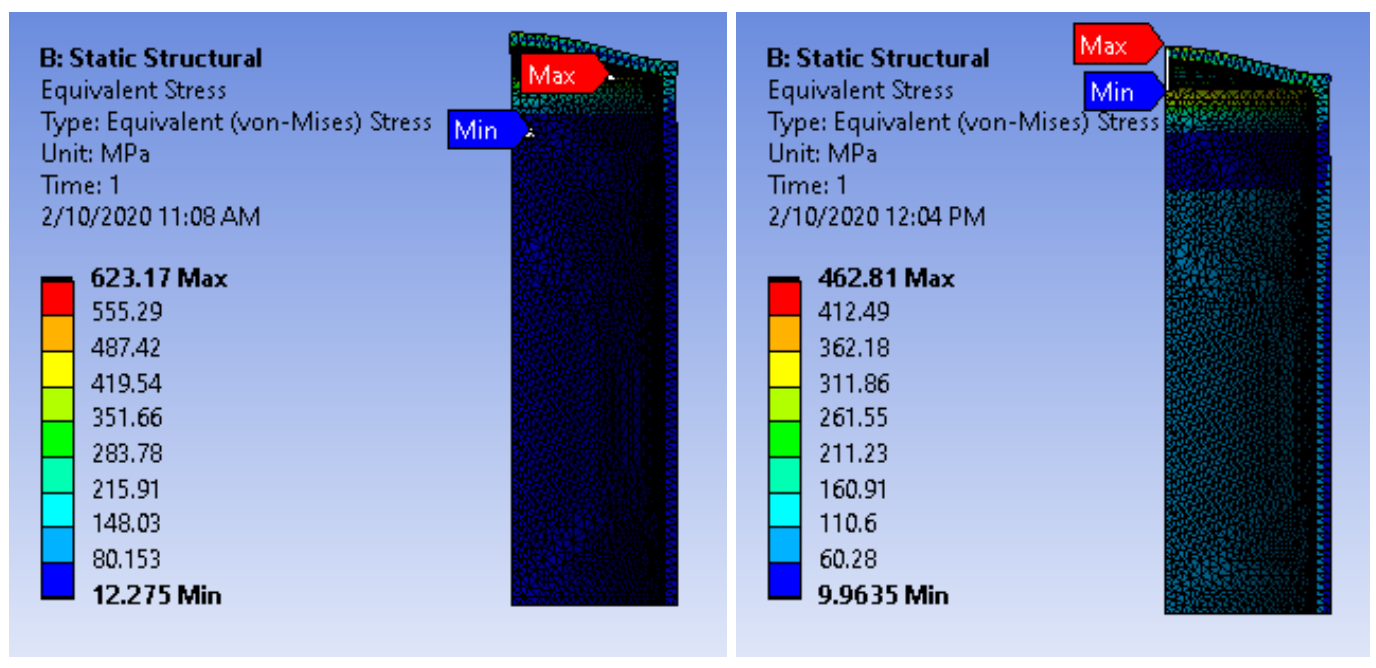

Gambar 4. Tegangan von Mises dengan ketebalan cap $5 \mathrm{~mm}$ untuk radius fillet $2 \mathrm{~mm}$ (kiri) dan $4 \mathrm{~mm}$ (kanan)

Gambar 5 menunjukkan tegangan von Mises silinder dengan radius fillet $8 \mathrm{~mm}$ untuk ketebalan cap $5 \mathrm{~mm}$ (kiri) dan $10 \mathrm{~mm}$ (kanan). Hasil simulasi menunjukkan tegangan von Mises maksimum menurun seiring peningkatan ketebalan cap (Tabel 3). Hubungan antara ketebalan cap dan tegangan von Mises maksimum berbanding terbalik. 

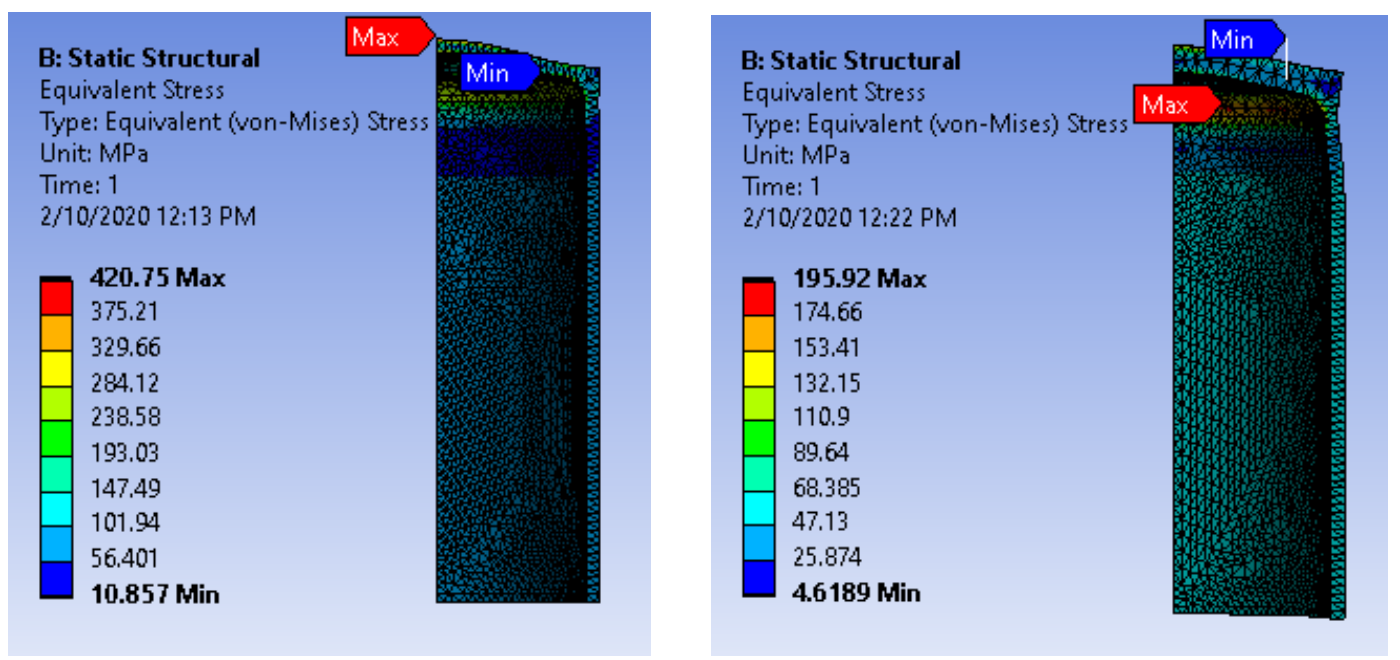

Gambar 5. Tegangan von Mises silinder dengan radius fillet $8 \mathrm{~mm}$ untuk ketebalan cap $5 \mathrm{~mm}$ (kiri) dan $10 \mathrm{~mm}$ (kanan).

Tabel 3. Tegangan von Mises maksimum untuk variasi radius fillet dan ketebalan cap

\begin{tabular}{ccccc}
\hline $\begin{array}{c}\text { Radius fillet } \\
(\mathbf{m m})\end{array}$ & $\begin{array}{c}\text { Ketebalan cap } \\
(\mathbf{m m})\end{array}$ & Jumlah node & Jumlah elemen & $\begin{array}{c}\text { Tegangan von Mises maksimum } \\
(\mathbf{M P a})\end{array}$ \\
\hline 2 & 5 & 31811 & 17733 & 623,17 \\
4 & 5 & 32053 & 17868 & 462,81 \\
6 & 5 & 32281 & 18004 & 442,07 \\
8 & 5 & 31608 & 17620 & 420.75 \\
\hline 2 & 10 & 32810 & 18368 & 273,25 \\
4 & 10 & 31996 & 17873 & 241,00 \\
6 & 10 & 31322 & 17445 & 220,19 \\
8 & 10 & 31404 & 17506 & 195,92 \\
\hline
\end{tabular}

Faktor keamanan digunakan untuk mengevaluasi keamanan komponen atau struktur meskipun dimensi yang digunakan minimum [17]. Faktor keamanan dapat didasarkan pada salah satu batas tegangan tarik maksimum atau tegangan luluh dari material [18]. Kekuatan luluh adalah tegangan minimum saat material mulai kehilangan sifat elastisnya, yaitu sifat material untuk kembali ke bentuk semula saat beban atau gaya dihilangkan [19]. Kekuatan tarik maksimum adalah tegangan maksimum yang mampu dicapai suatu material sebelum patah. Faktor keamanan pada kekuatan luluh bertujuan untuk mencegah deformasi yang merugikan, sedangkan faktor keamanan pada kekuatan tarik maksimum bertujuan mencegah keruntuhan. Faktor keamanan kurang dari 1 menunjukkan kegagalan permanen dari sebuah desain [20]. Pada penelitian ini, faktor keamanan berdasarkan pada kekuatan tarik maksimum (tensile strength) karena tabung roket bukan komponen yang digunakan secara berulang-ulang. Hal ini karena sifat tabung roket yang merupakan komponen habis pakai.

Gambar 6 menunjukkan pengaruh radius fillet dan ketebalan cap terhadap faktor keamanan dengan tekanan internal konstan, yaitu $6 \mathrm{MPa}$. Hasil simulasi menunjukkan bahwa ketika radius fillet dan ketebalan cap meningkat, maka faktor keamanan juga meningkat. Hubungan antara radius fillet dan ketebalan cap terhadap faktor keamanan adalah linear. 
Hasil analisis elemen hingga menunjukkan ketika ketebalan cap $10 \mathrm{~mm}$ dengan radius fillet 4, 6, dan $8 \mathrm{~mm}$ material memiliki faktor keamanan lebih tinggi dari 1,25. Hal ini berarti material tersebut mampu menahan beban statik. Hal ini berarti material tersebut mampu menahan beban statik karena nilai faktor keamanan untuk suatu material mampu menahan beban statik adalah 1,25-2,00 [21].

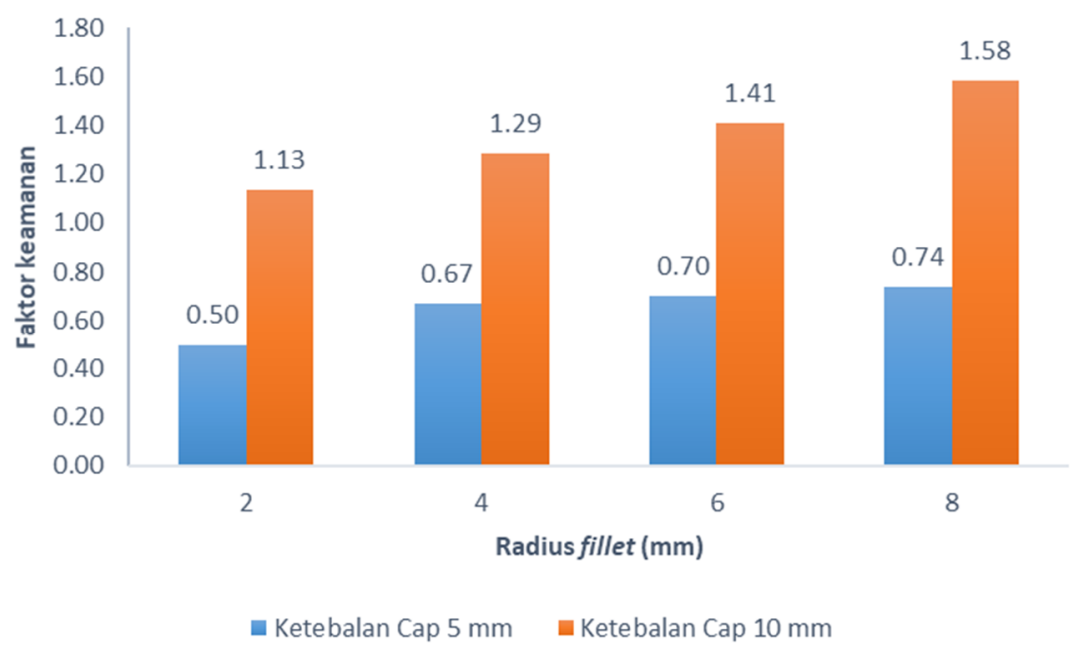

Gambar 6. Pengaruh radius fillet dan ketebalan cap terhadap faktor keamanan dengan tekanan internal $6 \mathrm{MPa}$

Proses verifikasi dilakukan dengan membandingkan nilai tegangan hoop dan longitudinal antara perhitungan analitik dan analisis elemen hingga. Semakin kecil persentase kesalahan menunjukkan hasil analisis elemen hingga semakin valid. Gambar 7 menunjukkan nilai tegangan hoop (kiri) dan longitudinal (kanan) maksimum pada radius fillet 2 mm dengan ketebalan cap $5 \mathrm{~mm}$, yaitu 70,35 MPa dan 32,17 MPa. Hasil simulasi menunjukkan peningkatan radius fillet dan ketebalan cap tidak terlalu berpengaruh terhadap tegangan hoop dan longitudinal maksimum. Nilai tegangan hoop dan longitudinal yang dihasilkan relatif sama (Tabel 4). Kedua nilai tegangan menggunakan analisis elemen hingga dan perhitungan analitik tidak berbeda signifikan. Persentase kesalahan antara perhitungan analitik dan analisis elemen hingga kurang dari 5 persen.
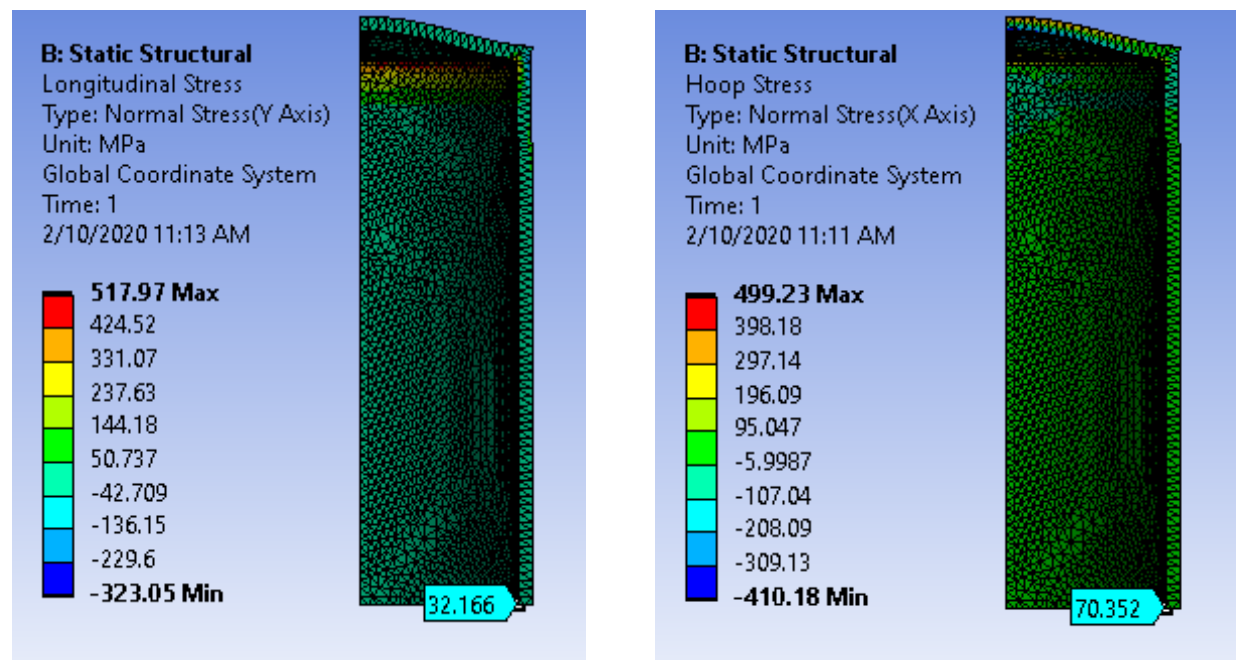

Gambar 7. Nilai tegangan hoop (kiri) dan longitudinal (kanan) maksimum pada radius fillet $2 \mathrm{~mm}$ dengan ketebalan cap $5 \mathrm{~mm}$ 
Tabel 4. Perbandingan tegangan hoop (circumferential) dan longitudinal (axial) maksimum antara perhitungan analitik dan simulasi elemen hingga

\begin{tabular}{|c|c|c|c|c|c|c|c|}
\hline \multirow{2}{*}{$\begin{array}{l}\text { Radius } \\
\text { fillet } \\
(\mathrm{mm})\end{array}$} & \multirow{2}{*}{$\begin{array}{c}\text { Ketebalan } \\
\text { cap } \\
(\mathbf{m m})\end{array}$} & \multicolumn{2}{|c|}{ Perhitungan analitik } & \multicolumn{2}{|c|}{ FEA } & \multicolumn{2}{|c|}{ Persentase kesalahan } \\
\hline & & $\begin{array}{c}\text { Tegangan } \\
\text { Hoop } \\
\text { (MPa) }\end{array}$ & $\begin{array}{c}\text { Tegangan } \\
\text { Longitudinal } \\
\text { (MPa) }\end{array}$ & $\begin{array}{c}\text { Tegangan } \\
\text { Hoop } \\
\text { (MPa) }\end{array}$ & $\begin{array}{c}\text { Tegangan } \\
\text { Longitudinal } \\
\text { (MPa) }\end{array}$ & $\begin{array}{c}\text { Tegangan } \\
\text { Hoop } \\
(\%)\end{array}$ & $\begin{array}{c}\text { Tegangan } \\
\text { Longitudinal } \\
(\%)\end{array}$ \\
\hline 2 & 5 & 67,2 & 33,6 & 70,35 & 32,17 & 4,69 & 4,26 \\
\hline 4 & 5 & 67,2 & 33,6 & 70,31 & 32,17 & 4,63 & 4,26 \\
\hline 6 & 5 & 67,2 & 33,6 & 70,34 & 32,16 & 4,67 & 4,29 \\
\hline 8 & 5 & 67,2 & 33,6 & 70,33 & 32,16 & 4,66 & 4,29 \\
\hline 2 & 10 & 67,2 & 33,6 & 70,34 & 32,16 & 4,67 & 4,29 \\
\hline 4 & 10 & 67,2 & 33,6 & 70,32 & 32,15 & 4,64 & 4,32 \\
\hline 6 & 10 & 67,2 & 33,6 & 70,35 & 32,16 & 4,69 & 4,29 \\
\hline 8 & 10 & 67,2 & 33,6 & 70,31 & 32,17 & 4,63 & 4,26 \\
\hline
\end{tabular}

Tegangan hoop selalu tarik (tensile), dan tegangan hoop maksimum selalu terjadi pada jari-jari dalam atau jari-jari luar tergantung pada arah gradien tekanan [22]. Jika silinder berdinding tipis hanya mengalami tekanan eksternal, maka tegangan hoop maksimum terjadi pada jari-jari luar $\left(r=r_{0}\right)$. Pada penelitian ini, silinder berdinding tipis hanya mengalami tekanan internal, maka tegangan hoop maksimum terjadi pada jari-jari dalam $\left(r=r_{i}\right)$.

Pada silinder tertutup, tekanan internal bekerja untuk mengembangkan tegangan di sepanjang sumbu silinder. Tegangan ini disebut tegangan longitudinal dan biasanya lebih kecil dari tegangan hoop. Pada penelitian ini, tegangan hoop lebih tinggi dari tegangan longitudinal.

\section{Kesimpulan}

Hasil simulasi menunjukkan bahwa ketika radius fillet dan ketebalan cap meningkat, tegangan Von Mises menurun. Material memiliki faktor keamanan lebih tinggi dari 1,25 ketika ketebalan cap $10 \mathrm{~mm}$ dengan radius fillet 4, 6, dan $8 \mathrm{~mm}$. Hal ini berarti material tersebut mampu menahan beban statik.

Proses verifikasi dilakukan dengan membandingkan hasil analisis elemen hingga dengan perhitungan analitik untuk tegangan hoop dan longitudinal maksimum dengan kondisi batas tetap. Hasil simulasi menunjukkan peningkatan radius fillet dan ketebalan cap tidak begitu berpengaruh terhadap tegangan hoop dan longitudinal maksimum. Kedua tegangan yang dihasilkan tersebut relatif sama. Hasil penelitian menunjukkan persentase kesalahan kurang dari 5 persen.

\section{Daftar Pustaka}

[1] L. A. N. Wibawa. Merancang Komponen Roket 3D dengan Autodesk Inventor Professional 2017. Buku Katta, 2018.

[2] W. Emrich. Rocket Engine Fundamentals. in Principles of Nuclear Rocket Propulsion. 2016, pp. 11-20.

[3] L. A. N. Wibawa., K. Diharjo., W. W. Raharjo., B. H. Jihad. Stress Analysis of Thick-Walled Cylinder for Rocket Motor Case under Internal Pressure. in Lecture Notes in Mechanical Engineering, Springer Nature. 2020.

[4] L. A. N. Wibawa., K. Diharjo., W. W. Raharjo., B. H. Jihad. Effect of Cap Thickness and Internal Pressure on 
Von Mises Stress of Thick-Walled Cylinder for Rocket Motor Case. J. Teknol. Dirgant. 2020, 18(1).

[5] L. A. N. Wibawa. Desain dan Analisis Kekuatan Dudukan (Bracket) AC Outdoor Menggunakan Metode Elemen Hingga. J. Crankshaft. 2019, 2(1): pp. 19-24.

[6] L. A. N. Wibawa. Desain dan Analisis Kekuatan Rangka Meja Kerja (Workbench) Balai LAPAN Garut Menggunakan Metode Elemen Hingga. JTM-ITI (Jurnal Tek. Mesin ITI). 2019, 3(1): pp. 13-17.

[7] L. A. N. Wibawa. Desain dan Analisis Kekuatan Rangka Lemari Perkakas di Balai LAPAN Garut Menggunakan Metode Elemen Hingga. Mach. J. Tek. Mesin. 2019, 5(2): pp. 45-50.

[8] A. F. Mohamed. Finite Element Analysis for Stresses in Thin-Walled Pressurized Steel Cylinders. Int. J. Sci. Eng. Res. 2018, 9(3): pp. 201-204.

[9] F. Dadkhah., J. Zecher. ANSYS Workbench Software Tutorial with Multimedia CD Release 11. Schroff Development Corporation, 2008.

[10] K. L. Lawrence. Ansys Workbench Tutorial Release 14. SDC Publications, 2012.

[11] L. A. N. Wibawa. Prediksi Umur Fatik Struktur Crane Kapasitas 10 Ton Menggunakan Metode Elemen Hingga. Media Mesin Maj. Tek. Mesin. 2020, 21(1): pp. 18-24.

[12] L. A. N. Wibawa. Desain dan Analisis Kekuatan Rangka Tricycle Landing Gear UAV Menggunakan Metode Elemen Hingga. Mechanical. 2018, 9(2): pp. 33-37.

[13] L. A. N. Wibawa. Desain dan Analisis Tegangan Crane Hook Model Circular Section Kapasitas 5 Ton Menggunakan Autodesk Inventor 2017. Simetris J. Tek. Mesin, Elektro dan Ilmu Komput. 2019, 10(1): pp. 2732.

[14] L. A. N. Wibawa. Desain dan Analisis Tegangan Alat Pengangkat Roket Kapasitas 10 Ton Menggunakan Metode Elemen Hingga. J. Energi dan Teknol. Manufaktur. 2019, 02(01): pp. 23-26.

[15] L. A. N. Wibawa. Pemodelan Umur Fatik Alat Pengangkat Roket Kapasitas 20 Ton Menggunakan Ansys Workbench. Turbul. J. Tek. Mesin. 2019, 2(2): pp. 44-49.

[16] L. A. N. Wibawa. Pengaruh Kecepatan Landing Vertikal Terhadap Ketahanan Beban Impak Rangka Landing Gear Menggunakan Metode Elemen Hingga. Angkasa J. Ilm. Bid. Teknol. 2019, 11(1): pp. 35-42.

[17] L. A. N. Wibawa. Simulasi Kekuatan Komponen Sarana Pengujian Roket Menggunakan Autodesk Inventor Professional 2017. Buku Katta, 2018.

[18] L. A. N. Wibawa. Pengaruh Susunan dan Jumlah Lubang Baut Terhadap Kekuatan Rangka Main Landing Gear Untuk Pesawat UAV. Flywheel J. Tek. Mesin Untirta. 2019, 5(1): pp. 46-50.

[19] L. A. N. Wibawa. Pengaruh Diameter Baut Terhadap Kekuatan Rangka Main Landing Gear Pesawat UAV Menggunakan Metode Elemen Hingga. J. Polimesin. 2019, 17(1): pp. 26-32.

[20] L. A. N. Wibawa., K. Diharjo. Desain, Pemilihan Material, dan Faktor Keamanan Stasiun Pengisian Gawai Menggunakan Metode Elemen Hingga. J. Teknol. 2019, 11(2): pp. 97-102.

[21] K. Z. V. Dobrovolsky. Machine elements : a textbook. Moscow: Peace Publisher, 1978.

[22] L. Skinner. Snubbing Theory and Calculations. in Hydraulic Rig Technology and Operations, Gulf Professional Publishing, 2018. pp. 189-275. 